\title{
a) Molecular Studies on Tomato Yellow Leaf Curl Virus in Infected Tomato and Pepper Plants
}

Younis, H.A ${ }^{1}$, N. A. Zaid ${ }^{2}$ and S. Deraz ${ }^{2}$

Since 1996 'Department of Agricultural Botany, Faculty of Agriculture (Saba-Bacha),

Alexandria University, University 21531, Egypt

${ }^{2}$ City for Scientific Research and Technology Applications,Burg-El-Arab,post code 43912

Egypt. Corresponding author: Z. Nehal, e-mail: nahlaz2015@gmail.com

DOI: $10.21608 /$ jalexu.2021.96238.1007

\section{Article Information}

Received:June $29^{\text {th }} 2021$

Revised: August $26^{\text {th }} 2021$

Accepted:October $\quad 10^{\text {th }}$ 2021

Published: October $11^{\text {th }}$ 2021
ABSTRACT: Tomato Yellow Leaf Curl (TYLC) is an economic disease that caused dramatic losses in tomato crops. It is caused by a monopartite whiteflytransmitted begomovirus individually or associated with Betasatellite DNAs. Recently, TYLC disease became more severe in Egypt, and it destroyed completely the tomato crop in some crop seasons during the year. Tomato and pepper samples with curling symptoms were brought from EL-Nubaria region, El Beheira governorate in Egypt and tested by Polymerase Chain Reaction (PCR) with specific primers to detect the presence of the causal begomovirus and its associated DNA betasatellites and/or the presence of new genotypes between two tomato yellow leaf curl virus (TYLCV) isolates. Disease symptoms varied between yellowing, curling and cup-shaped symptoms. PCR products indicated the presence of the two Mediterranean TYLC begomoviruses strains TYLCV-IL and TYLCV-MiLD, while no new genotypes of the virus or TYLCSV isolate were found in these samples. Additionally, betasatellites were found to be associated with the virus in all infected tomato and pepper samples either the betasatellite complete genome or its defective form. In conclusion, no TYLCV new genotypes were detected in the tested samples to be responsible for the severe tomato losses in EL-Nubaria region in El Beheira governorate, but TYLCV/Betasatellites association is expected to play an axial circumference in TYLC disease severity in the same region.

Keywords: Tomato Yellow leaf curl virus, Betasatellite DNA, PCR, new genotypes, El- Nubaria region. INTRODUCTION: Family Solanaceae members whitefly body and behaves away from the midgut are some of the most important economic crops in Egypt for both local consumption and exportation. During the last years, dramatic losses occurred for tomato plants in different localities in Egypt such as El Fayium governorate, EL-Nubaria and Wadi El Natron because of a severe infection with the tomato leaf curl virus (TYLCV) (Aboul-Ata et al., 2000; El-Dougdoug et al., 2014; Rabie et al., 2017 and Sofy et al., 2017). The tomato Yellow Leaf Curl Virus (TYLCV) is a monopartite begomovirus that belongs to the Geminiviridae family, which represents the circular, singlestranded DNA plant viruses (Lazarowitz, 1992) and involves more than 380 whiteflies (Bemisia tabaci)-transmitted species other than TYLCV (Zhao et al., 2019).

Whiteflies have piercing and sucking mouthparts utilized for feeding in plant phloem (Byrne and Bellows, 1991; Gill, 1990). It is known for obligating harboring besides the primary endosymbionts with their hosts (Campbell, 1993; Thao and Baumann, 2004), and synthesizing amino acids that are in inadequate amounts in phloem sap (Buchner, 1965; Morin et al., 1999, Rosell et al., 2009 and Gorovits and Czosnek 2013).This type of viruses circulates in the (MG) lumen till the hemolymph and, eventually, till the primary salivary glands (PSGs), where it is given back into the plant host pending insect feeding (Czosnek et al., 2002 and Matore, 2018). The minimum effective periods of either acquisition-access or inoculation-access are almost 10 to $20 \mathrm{~min}$ per each. While the latent period is about $8 \mathrm{~h}$ at minimum starting from the acquisition healthy plant. Begomoviruses are thought to be not capable of replicating in their insect vectors (Rosen et al., 2015, Gilbertson et al., 2015). However, strong evidence demonstrated by He, et al., (2020) gave an exception to TYLCV and proved its ability to replicate in its vector (Bemisia tabaci) mainly in the salivary glands (Navas-Castillo et al., 2011).

This monopartite genome $(2.8 \mathrm{~kb})$ consists of six proteins responsible for replication, transmission, pathogenesis, and movement functions (Jeske, 2009). TYLCV spreads in tropical and subtropical regions (Navas-Castillo et al., 2011) and has a wide host range as it infects numerous plant species causing considerable yield losses in many important crops either monocots or dicots; the mechanism of geminiviruses inside the plant is to reshape the intracellular environment of the host so is required for the insect to be able to infect a new Journal Article (C) 2021 by (JAAR) is licensed under CC BY-NC 4.0 CC) 
that create favorable conditions for replication and propagation of the virus (Mansoor et al., 2003; Mansoor et al., 2006 and Maio, 2020); The viral symptoms include plant stunting, erect shoots, small and misshaped leaflets, chlorotic, curling and cup-shaped leaves (Cohen and Nitzany, 1960). There are many TYLCV isolates globally which classified based on their origin (Cohen and Lapidot, 2007). In the Mediterranean East in particular, there are two main TYLCV isolates: TYLCV-IL from Israel and TYLCV-MID from the Mediterranean basin, besides Tomato Yellow leaf curl Sardinia virus (TYLCSV) from Italy (KheyrPour et al. 1991).

Betasatellites are circular single-stranded DNAs ranged between 660-1350 nucleotides in the Nile Basin area (Briddon et al., 2003 and Idris, et al., 2002). Although the existence of betasatellites was reported in some Mediterranean countries including Egypt (Conflon et al., 2018), betasatellite/begomovirus association needs more survey and study to estimate the risk of betasatellites on the disease severity and incidence. Experimentally, TYLCV was found to be the helper of most of the various DNA betasatellites with which it is co-inoculated (Ito et al., 2009; Kon et al., 2009; Ueda et al., 2012 and Zhang et al., 2012), and the most noticeable matter, all of them enhanced its virulence.

Tomato and pepper have been reported as a symptomatic TYLCV host (Moury and Verdin 2012); (El-Dougdoug et al., (2014) detected TYLCV in tomato and pepper plants from different areas in Egypt using polymerase chain reaction (PCR) and degenerate primers, the targeted sequence $(\sim 530 \mathrm{bp})$ in that reaction was of the coat protein gene $(\mathrm{CP})$ of Begomoviruses. The resulted DNA sequence of this investigation showed high nucleotide identities (up to 99\%) to isolates of TYLCV in the GenBank; Moreover, Rabie et al., (2017) sampled TYLCV symptomatic tomato crops from different regions in Egypt during the year 2014, Israel and Mild TYLCV strains were detected in these samples by multiplex and realtime PCR. The complete sequence genome of the Egyptian isolate obtained in this study showed a high degree of identity to other reported Egyptian isolates in addition to TYLCV-IL Jordan isolate and TYLCV-IL Japan isolates.

Because of begomoviruses' high capability to recombine, Fauquet et al, 2005, mentioned that new recombinants of begomoviruses were expected to be emerged with higher virulence and altered host range. For instance, Tomato yellow leaf curl Axarquia virus (TYLCAxV) recombinant was detected from the highly recombinogenic isolates TYLCV and TYLCSV in Spain (GarciaAndres et al., 2006). Also, Belabess et al., 2015, reported a new recombinant named TYLCV IS76 which has been discovered in 2010 from both isolates in southern Morocco; the emergence of this recombinant coincided with the increasing use of tolerant cultivars in the 2000s. However, although so many Mediterranean countries are using tolerant tomato cultivars, TYLCV-IS76 was not detected outside Morocco (Belabess et al. 2018).

Recently, some begomoviruses in Egypt like the Squash leaf curl virus (SLCEGV) were found to be joined with a DNA molecule defined as betasatellite; for example, Abdel-Salam et al., 2017; examined betasatellites/ SLCEGV association in different crops in Egypt around 4 years by various molecular techniques. He finally concluded that the genomic mixture of SLCEGV and the possible acquisition of betasatellites by SLCEGV modified the viral virulence and fitness. Briddon et al., 2003 and Sivalingam, and Varma, 2012 proved that betasatellites had an effective role in begomoviruses accumulation and severe symptoms appearance and Conflon et al., 2018 supported the same idea by their study which illustrated that all resistant tomato plants coinfected with Cotton leaf curl Gezira betasatellites and TYLCV IL/MILD showed leaf curling and mosaic symptoms, while the same resistant cultivar inoculated only with TYLCV was asymptomatic.

The main objectives of this study is testing the introduction of TYLCV new recombinants to Egypt after the epidemic appearance of TYLCV in some tomato production areas like EL-Nubaria in El Beheira Governorate and test the role of betasatellites in exhibiting symptoms in tomato and pepper plants.

\section{MATERIALS AND METHODS \\ TYLCV - infected tomato sampling (first season, 2019)}

Tomato symptomatic samples were collected from EL-Nubaria region, El Beheira governorate during the late summer of the year 2019. All collected samples were classified and labeled as follows: Infected tomato with clear yellowing and curling symptoms (Ts), infected tomato with unclear yellowing and curling symptoms (Tas), and infected pepper with curling symptoms $\left(\mathrm{P}^{\prime}\right)$. These samples were tested to detect the presence of different genotypes of TYLCV including TYLCSV, Betasatellites and the native isolates TYLCV- IL and TYLCV- MiLD that are previously detected in the Mediterranean East. Samples freeze at -20 for DNA extraction and molecular analysis.

\section{DNA extraction}


DNA was extracted from the tested leaf samples by the CTAB method according to Gabriadze et al., (2014) and Belabess et al., (2015) with some modifications in the speed of the centrifugation step. A sample of $20 \mathrm{mg}$ of each plant leaf was ground and mixed in a sterile tube with $500 \mu \mathrm{l}$ CTAD buffer, tubes were incubated for $30 \mathrm{~min}$ in $65^{\circ} \mathrm{C}$ water bath and inverted three or four times during which; samples were centrifuged for $15 \mathrm{~min}$ at $2900 \mathrm{rpm}$ then each supernatant was transferred to a new tube with $450 \mu \mathrm{l}$ chloroform, the mixture was stirred at room temperature for $5 \mathrm{~min}$ followed by centrifugation for $10 \mathrm{~min}$ at $2900 \mathrm{rpm} .350 \mu \mathrm{l}$ of the aqueous phase was mixed with $350 \mu \mathrm{l}$ of isopropanol and the mixture was centrifuged at $2900 \mathrm{rpm}$ for $15 \mathrm{~min}$. The pellet was washed with $70 \%$ ethanol and after a complete drying from ethanol, the samples were re-dissolved in $50 \mu \mathrm{l}$ of TE buffer and stored at -20 for further analysis.

\section{Polymerase chain reaction $(\mathrm{PCR})$ reactions}

All the PCR reactions were performed by Cosmo PCR master mix W1020300X, Willowfort Co., following the manufacturer's instructions. PCR conditions were set up for each program individually based on primers used.

Detection of $\underline{A}$ component genome (DNA-A) of begomoviruses

DNA-A of begomoviruses was tested by specific primers according to Abd El Salam et al. (2017) which were designed to amplify the fragment of the DNA-A coat protein (580 bp). The DNA primers were AV Core 5'GCCHATRTAYAGRAAGCCMAGRAT3' and $\mathrm{AC}$

Core5'GGRTTDGARGCATGHGTACANGCC3'.

\section{Detection of Betasatellites}

Betasatellites complete genome and their defective genome were detected by specific primers according to Abd El Salam et al., (2017). The expected products were $1300 \mathrm{bp}$ and $700-1000 \mathrm{bp}$, respectively. The DNA primers were $\beta 01(\mathrm{~F})$ 5'GGTACCACTACGCTACGCAGCAGCC3' and $\beta 02$

GGTACCTACCCTCCCAGGGGTACAC3' PCR for betasatellites and DNA-A of begomovirus was conducted under the same conditions of $95^{\circ} \mathrm{C}$ for $5 \mathrm{~min}$ as denaturation step followed by 30 cycles of $95^{\circ} \mathrm{C}$ for $1 \mathrm{~min}$, primer annealing step at $58^{\circ} \mathrm{C}$ for $1 \mathrm{~min}$, extension step at $72^{\circ} \mathrm{C}$ for $1 \mathrm{~min}$ and final extension at $72{ }^{\circ} \mathrm{C}$ for $7 \mathrm{~min}$. Electrophoresis gel was performed in $1 \%$ agarose and stained with Ethidium bromide.

\section{TYLCV/TYLCSV recombinants (PCR1)}

The degenerate primers mixture was used in this reaction to detect the presence of TYLCSV isolate and/or its recombinants TYLCV-IL/TYLCSV,
TYLCV-MID/TYLCSV at locus OR (Origin of Replication). The expected products of this reaction were $405 \mathrm{bp}, 187 \mathrm{bp}$, and $548 \mathrm{bp}$, respectively.

PCR1 primer mixture (Belabess et al., 2015) The DNA primers were Sar43R 5'TGCGTAGGDCCYACTWCTTTATCGG-3' / Mild 2277F 5'-CTSWCCCCARTCGABGGTG-3'/ IL2629F 5'-GGTGTCCCTCAAAGCTCTAWG3'/TYS2416 F1* 5'CCCTCGAACTGAATGAGCATG-3'/ and TYS2416 F2* 5'CCYTCGAAYTGSATGAGAAYA-3'.

\section{TYLCSV/TYLCV recombinants (PCR2)}

The second specific primers mixture was used in this reaction to detect the presence of TYLCV isolates IL and Mild and/or its recombinants TYLCSV/TYLCV. The expected products of this reaction were $230 \mathrm{bp}, 592 \mathrm{bp}$ and $440 \mathrm{bp}$, respectively.

PCR2 primer mixture (Belabess et al., 2015): TY78R5'

GCAATTTGATTGGTTGAYAGTSACR-

3'/IL2629F5' GGTGTCCCTCAAAGCTCTAWG3'/Mild2277F 5'CTSWCCCCARTCGABGGTG3'/TYS2416F1*5'-

CCCTCGAACTGAATGAGCATG-

3'/TYS2416F2*5'CCYTCGAAYTGSATGAGAA YA-3'

PCR1 and PCR2 were performed under the same conditions of denaturation step at $95^{\circ} \mathrm{C}$ for $5 \mathrm{~min}$, followed by 30 cycles of $95^{\circ} \mathrm{C}$ for $45 \mathrm{sec}, 60^{\circ} \mathrm{C}$ for $45 \mathrm{sec}, 72{ }^{\circ} \mathrm{C}$ for $45 \mathrm{sec}, 72{ }^{\circ} \mathrm{C}$ for $10 \mathrm{~min}$. Electrophoresis gel was performed in $1.5 \%$ agarose and stained with Ethidium bromide.

\section{RESULTS AND DISCUSSION}

Detection of (A) Component of Begomoviruses and Betasatellites in Tomato from El-Nobaria region

Tomato and pepper samples were collected at the end of the season at the maturity stage of their life cycle. Tomato samples from EL-Nubaria region were classified based on symptoms appearance as shown in Figure 1 (A, B and C). (A) shows tomato plants with curling and yellowing symptoms; (B) shows tomato plants with only yellowing symptoms, while severe curling symptoms on pepper plant samples illustrated in $\mathrm{C}$.

Regardless the etiology of this differentiation in symptoms degrees, it may be attributed to plant stage at the time of infection. Brown (2000) reported that TYLCV infection of tomato plants in the early stage causes severe symptoms. Short- 
(JAAR) Volume: 26 (3)

developed leaves after infection are cupped upward rolled-leaf margins and curling between downward; while later-developed leaves are the veins.

prominently chlorotic and deformed in addition to

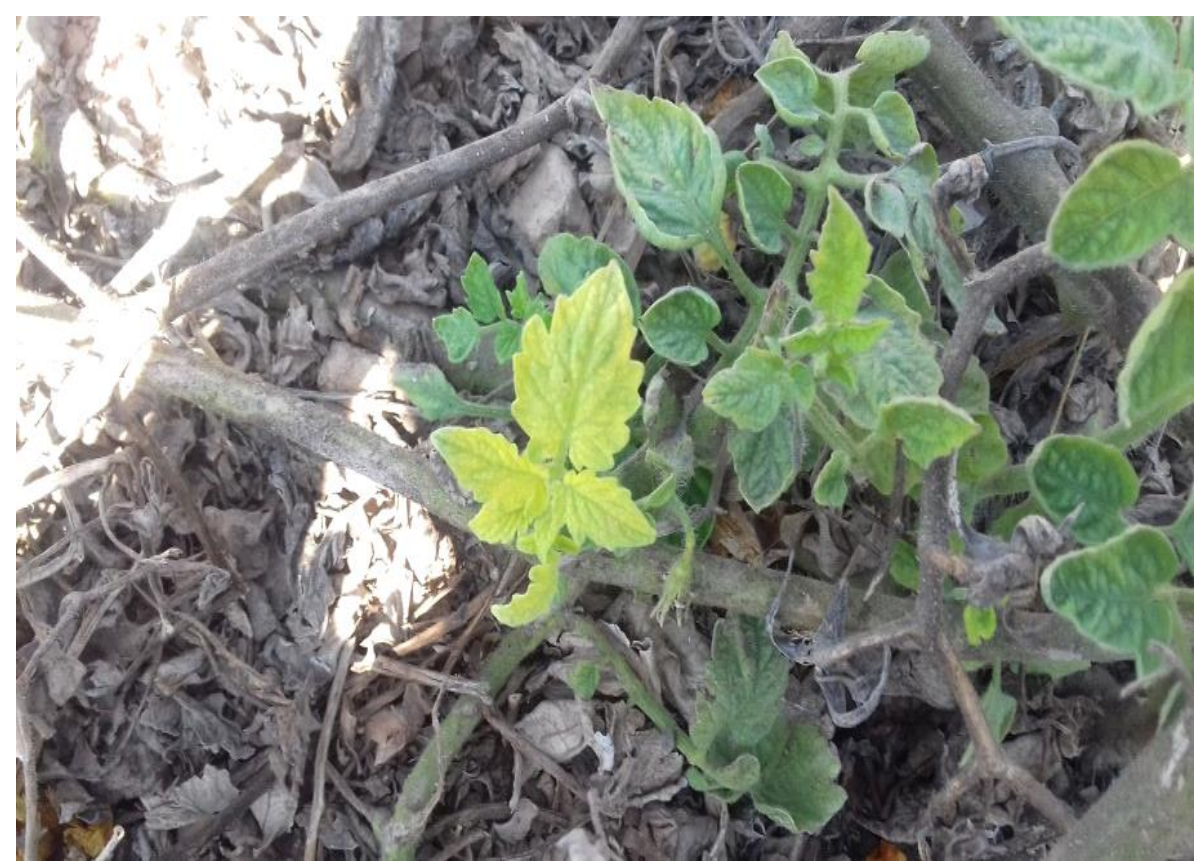

(A): Clear Yellowing, curling and cup-shaped symptoms on tomato leaves (Ts).

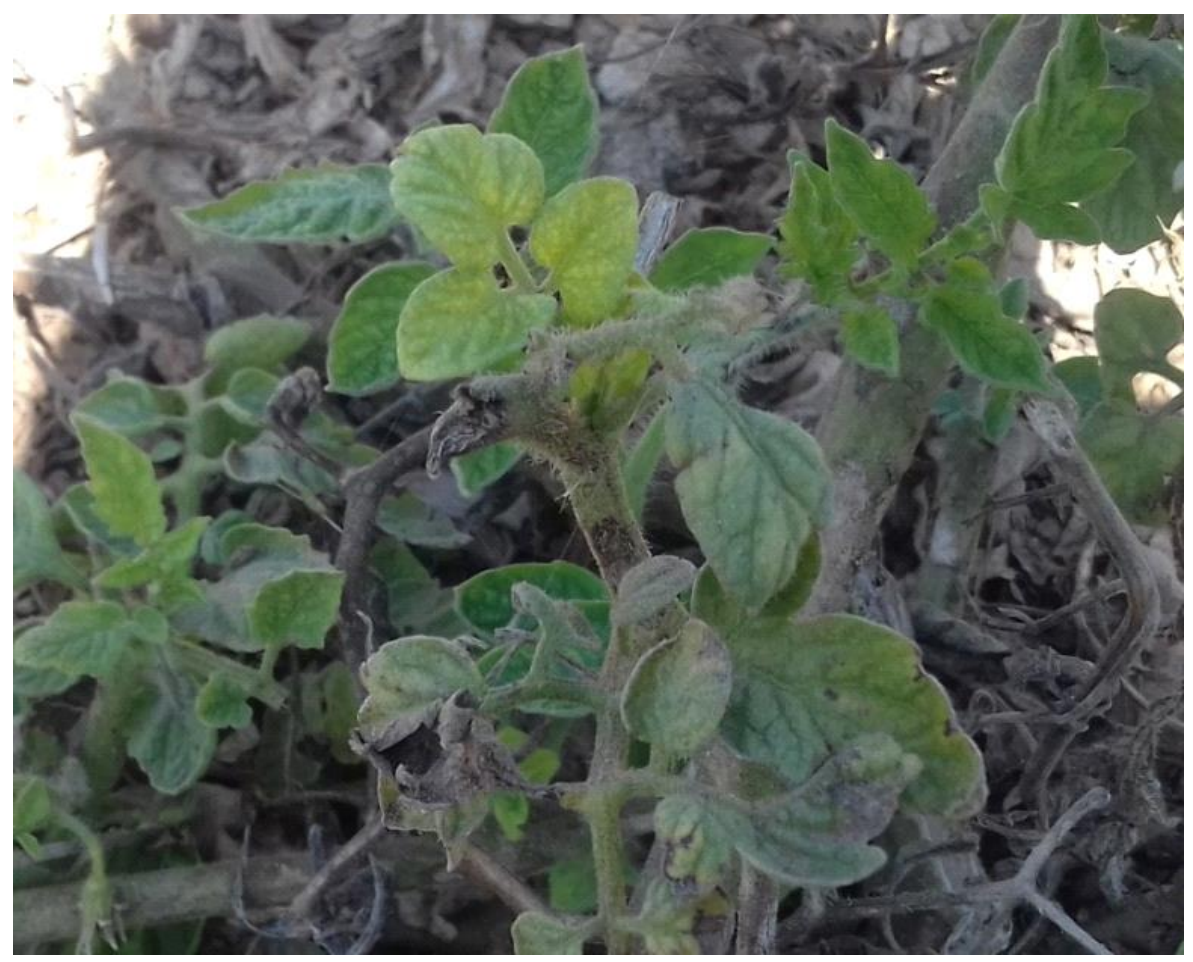

(B): Unclear yellowing and curling symptoms on tomato leaves (Tas) . 


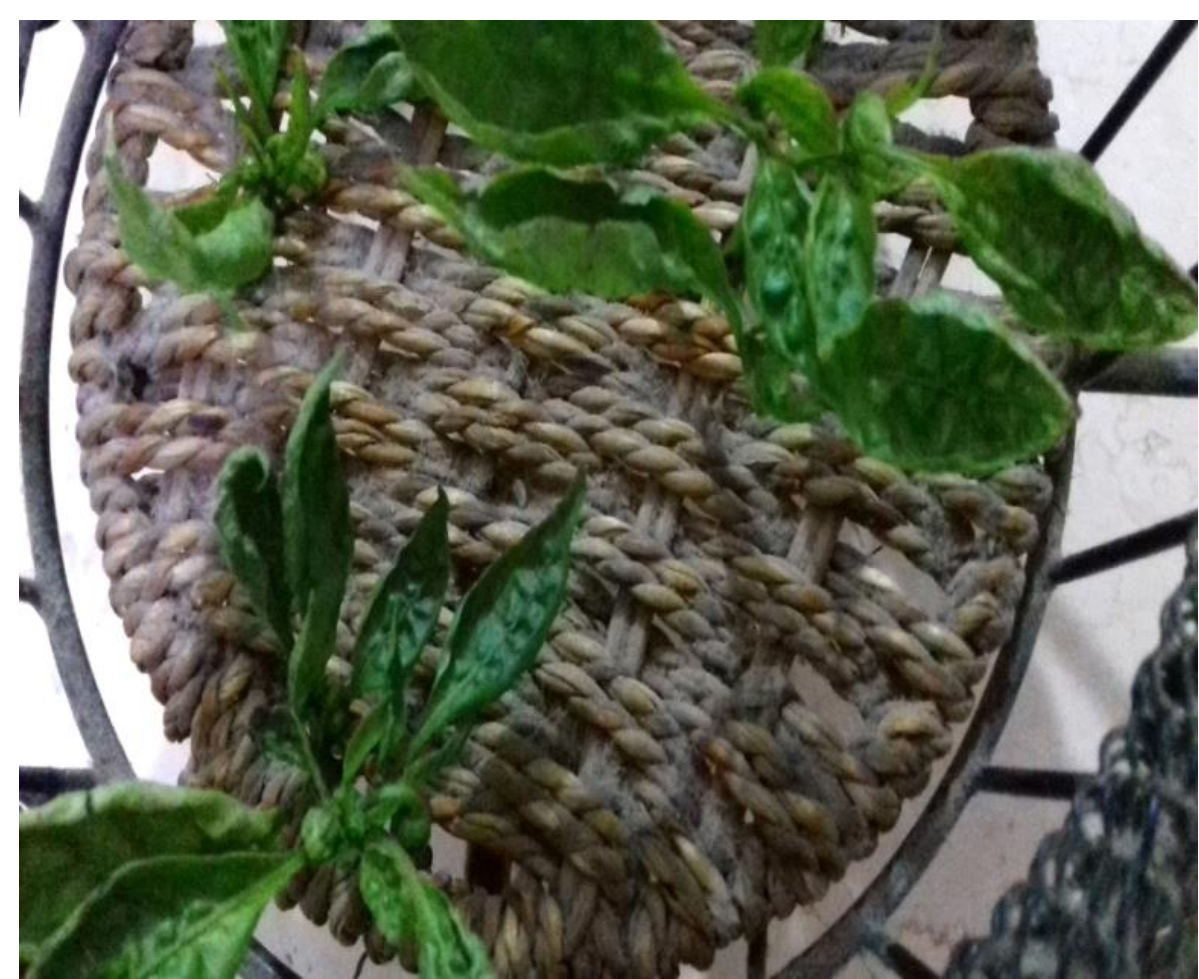

(C): curling and cup-shaped symptoms on pepper leaves $\left(\mathrm{P}^{\prime}\right.$ and $\left.\mathrm{P}^{\prime \prime}\right)$

Fig.1: TYLCV various symptoms on tomato and pepper plants (A, B and C).

\section{Detection of Begomoviruses and Betasatellites in Tomato and Pepper}

The results showed that both clear and unclear symptomatic tomato plants have a DNA A fragment of begomoviruse ( 580bp) clearly appeared in the two frequencies of each (Figure 2). Similarly, the betasatellites complete genome ( 1300bp) or its defective form (700-900bp) was observed at the same samples. However, the complete genome appeared in a high concentration in the (Ts) tomato samples with its defective form, while it was appeared in a lower concentration in the (Tas) tomato samples with a more concentrated band for its defective form (Figure 2). PCR test for pepper proved the presence of A component genome (DNA A) of begomovirus in the two pepper sample frequencies coincided with the presence of Betasatellite DNAs and its defective form in the same frequencies but in low concentration (Figure 3). This begomovirus/betasatellite association was reported previously by (Dry et al., 1997; Briddon et al., 2003; Idris et al., 2005; Idris et al., 2011 and FialloOlivé et al., 2012. Abdel Salam et al., (2017) found that betasatellite DNA association with Squash leaf curl bipartite begomovirus led to increasing the biodiversity of the virus through modifying its virulence and fitness.

TYLCV degenerate primers used in this experiment indicated that the two Mediterranean TYLCV strains IL and MiLD were detected in tomato, while only IL strain was found in pepper (Figure 4). Noteworthy, Conflon et al., (2018) mentioned that TYLCV accumulation increased in the mixed infection of betasatellite with TYLCVIl, while those of TYLCV-Mld/betasatellite infection decrease this accumulation in plants.

Usually, severe or moderate TYLCV infection is determined by two interfering factors: Efficiency of Ty1 gene-bearing cultivars, which play an important role in TYLCD severity with a variable immune mechanism such as encoding RNAdependent RNA polymerase or viral transcriptional gene silencing by allelic genes Ty-1 and Ty-3 (Verlaan et al., 2013; Caro et al., 2015); or TYLCV resistance locus Ty-2, which was genetically linked to the gene TYNBS1 that encodes an NB-LRR (Nucleotide-Binding domain and Leucine-Rich Repeat) protein a type of plant immune receptor (Yamaguchi et al., 2018). Nevertheless, many recent suggestions refer that these resistance cultivars no longer being effective against TYLCV because of new present or coming breaking strains of the virus under field conditions (Verlaan et al., 2013; Butterbach et al., 2014; Belabess et al., 2016; Ohnishi et al., 2016). The second factor is betasatellites, which play an axial circumference in TYLCV severity. Generally, betasatellites are considered pathogenicity determinants (Voorburg et al., 2020) because of their ability to produce the single protein $\mathrm{BC} 1$ which takes part in virus pathogenicity Saeed, (2010). This BC1 protein was proved to increase symptoms expression (Cui et al., 2004; Saunders et al., 2004), works as post transcriptional gene silencing (PTGS) suppressor (Amin et al., 2011; 
Cui et al., 2005) and in the systemic movement of the virus in plants (Briddon and Stanley 2006). Voorburg et al. (2020) showed in a study performed on ty-1 transformants of Nicotiana benthamiana and tomato plants that TYLCV accumulation was increased when plants co-

\section{A component}

1Kb Ts Tas

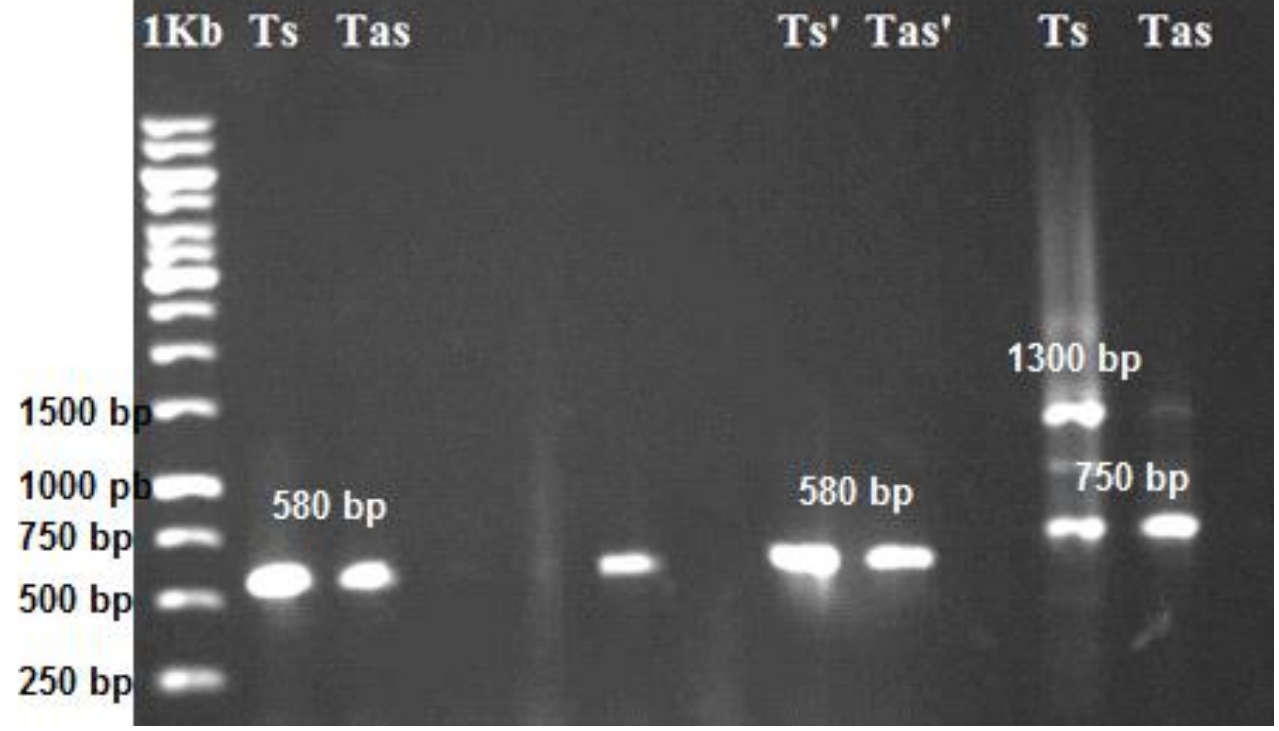

Fig. 2: Detection of A component (580 bp) of begomoviruses and $\beta$ DNAs CG (Complete genome $\sim 1300$ bp) and $\beta$ DNAs DF (Defective form 700-1000 bp) in symptomatic and asymptomatic tomato.

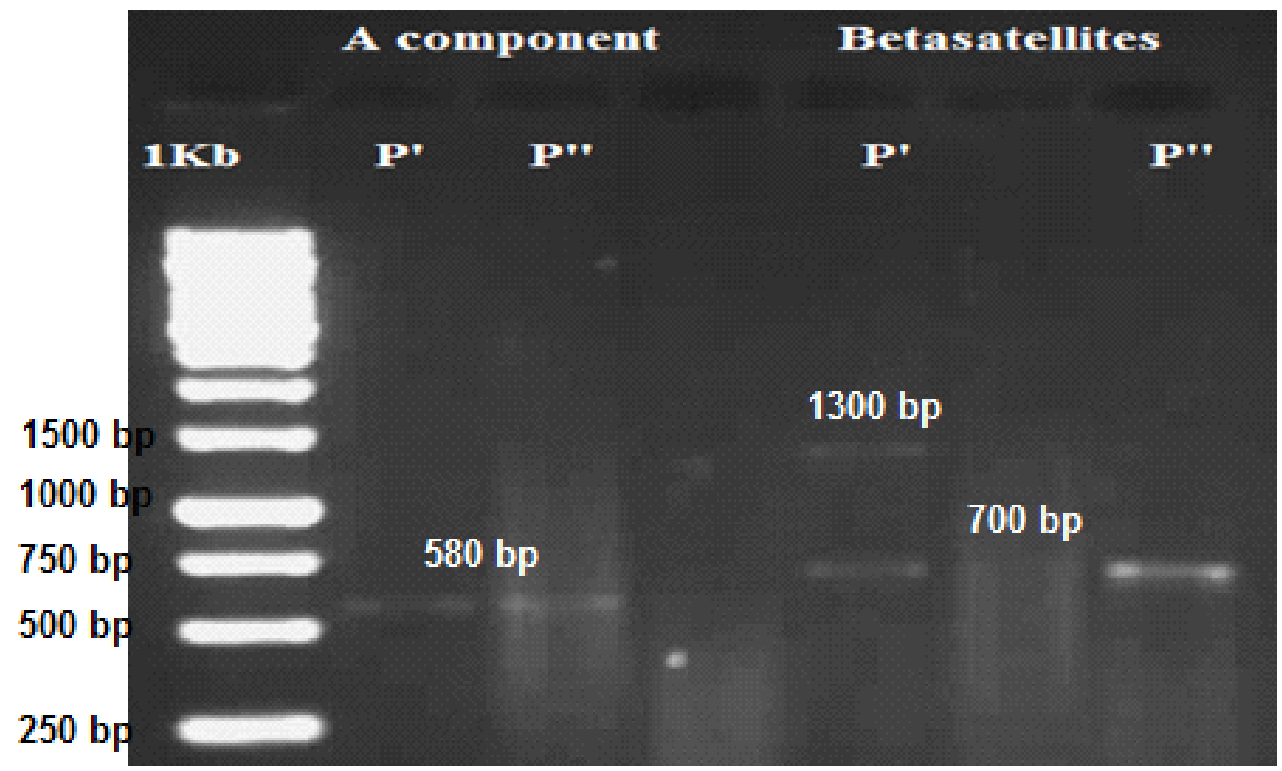

Fig. 3: Detection of A component of begomoviruses and betasatellites in symtomatic pepper. 


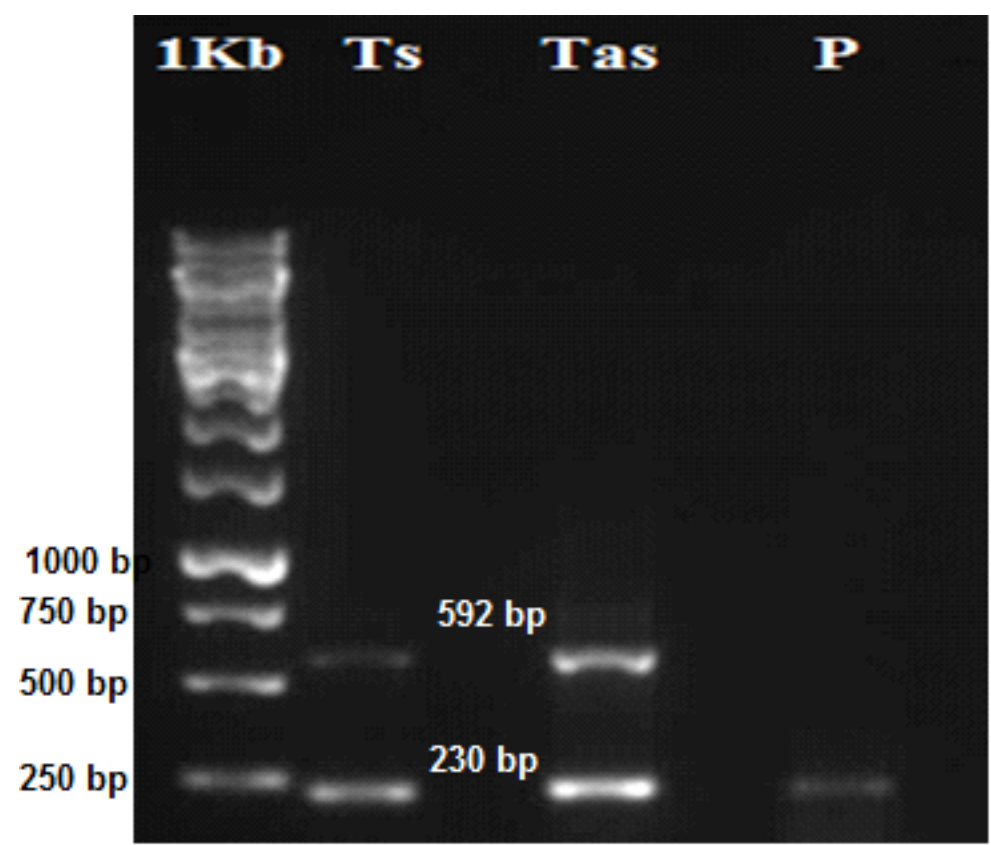

Fig. 4: Detection of TYLCV IL (230 bp)/ TYLCV MiLD (592 bp) strains with degenerate primers in tomato and pepper.

Detection of Parental Isolates and new genotypes of TYLCV in Tomato and Pepper:

The two multiplex PCR tests performed in this study were used to test the presence of new recombinants of TYLCV in El-Nubaria region. Often, having a new strain or recombinant from a viral genome happens due to genetic selection through mutation or recombination actions
(Fleischmann, 1996). Lefeuvre et al., (2010) found that the epidemiology of TYLCV variants in the western Mediterranean and the Middle East resulted from recombination. The results of our study illustrate that there is no new genotypes were found in tomato and pepper samples either from TYLCSV/TYLCV or TYLCV/TYLCSV recombination (Figure 5);
$1 \mathrm{~Kb}$
$\mathrm{Ts}$

$1000 \mathrm{bp}$

750 bp

500 bp

$250 \mathrm{bp}$

\section{TYLCV/TYLCSV Rec, + TYLCSV Iso.}

\section{TYLCSV/TYLCV Rec. + TYLCV (IL or Mid) Iso.}

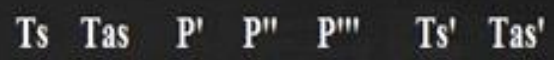

Fig. 5: Detection of TYLCV genotypes, no new genotypes or TYLCSV isolate were found in tomato and pepper samples, while only the native isolates of TYLCV (IL and MiLD) were detected.

Additionally, it illustrates the absence of the parental isolate TYLCSV. So, there were no new genotypes have been introduced to this area from any new imported seeds or seedlings. Likewise, 
what happed before in different countries; for instance, Mabvakur et al., (2016) indicated that the epidemic distribution of TYLCV in Australia and China originated by the introduction of the virus from Eastern-Asia around Japan and Korea. Moreover, the author found that the New Caledonian epidemic was imported by a cultivar from the Mediterranean West region and the Mauritian epidemic was a result of an imported cultivar from the neighboring island of Reunion. By contrast, IS76 recombinant that has been detected in Morocco by Belabess et al., (2015) was not detected in any other neighboring countries outside Morocco (Belabess et al., 2018)

\section{CONCLUSION}

There were no imported genotypes to El Nubaria region in El Beheira governotate during the last years; but both IL ( 230 pb) and Mid ( 592) strains of TYLCV appeared in tomato and pepper plants associated with DNA betasatellites that has been reported to strongly affect the virus severity on plants.

\section{ACKNOWLEDGMENT}

Special thanks to Dr. Cica URBINO and Dr. Michel Peterschmitt, Plant Virologists, HDR at CIRAD Montpellier, France for guiding me in the molecular section of this study.

\section{Conflicts of interest/Competing interests}

The authors of this study declare that they all accept the publication of these data and they have no conflict with each other or any other external scientist could prevent the publishing this work.

\section{Availability of data and material}

The data used to support the findings of this study are included within the article

\section{Code availability}

The coding of the data is available from the corresponding author upon reasonable request.

\section{Authors' contributions}

The first author is the owner of the main idea of the study.

The second author provided some materials and implemented the practical work of the idea.

The third author provided the lab supplies and facilities.

\section{Ethics approval}

The study have been conducted with no opposition with the scientific ethics.

Consent to participate

All authors accept the publication of these data.

\section{REFERENCES}

Abdel-Salam, A. M., M. Mujaddad-UrRehman, and S. M. El-Saghir. 2017. Genetic diversity, natural host range and molecular pathogenesis of Begomovirus-associated Betasatellites in Egypt. International Journal of Virology, 13(1): 29- 42.

Aboul-Ata, A. E., M. A. E. Awad, S. Abdel-Aziz, D. Peters, H. Megahed and A. Sabik. 2000. Epidemiology of tomato yellow leaf curl begomovirus in El-Fayium area, Egypt. EPPO Bulletin, 30(2): 297-300.

Amin, I., K. Hussain, R. Akbergenov, J. S. Yadav, J. Qazi, S. Mansoor, T. Hohn, C. M. Fauquet and R.W. Briddon. 2011. Suppressors of RNA silencing encoded by the components of the Cotton leaf curl begomovirus-betasatellite complex. Molecular Plant-Microbe Interactions, 24(8): 973-983.

Belabess, Z., M. Peterschmitt, M. Granier, A. Tahiri, A. Blenzar and C. Urbino. 2016. The non-canonical tomato yellow leaf curl virus recombinant that displaced its parental viruses in southern Morocco exhibits a high selective advantage in experimental conditions. Journal of General Virology, 97(12): 3433-3445.

Belabess, Z., S. Dallot, S.El-Montaser, M. Granier, M. Majde, A. Tahiri, A. Blenzar, C. Urbino and M. Peterschmitt. 2015. Monitoring the dynamics of emergence of a noncanonical recombinant of tomato yellow leaf curl virus and displacement of its parental viruses in tomato. Virology, 486: 291-306.

Belabess, Z., C. Urbino, M. Granier, A. Tahiri, A. Blenzar and M. Peterschmitt. 2018. The typical RB76 recombination breakpoint of the invasive recombinant tomato yellow leaf curl virus of Morocco can be generated experimentally but is not positively selected in tomato. Virus research, 243: 44-51.

Briddon, R.W. and J. Stanley. 2006. Subviral agents associated with plant single-stranded DNA viruses. Virology, 344(1): 198-210.

Briddon, R.W., E.B. Simon, I. Amin, A.M. Idris, S. Mansoor, I.D. Bedford, P. Dhawan, N. Rishi, S.S. Siwatch, A.M. Abdel-Salam, J.K. Brown, Y. Zafar and P.G. Markham. 2003. Diversity of DNA beta, a satellite molecule associated with some monopartite begomoviruses. Virology, 312: 106-121.

Brown, J.K. 2000. Molecular marker for the identification and global tracking of whitefly vector-begomovirus complexes. Virus research, 71: 233-260.

Buchner, P. (1965). Endosymbiosis of animals with plant microorganisms (No. QH548 B743).

Butterbach, P., M. G. Verlaan, A. Dullemans, D. Lohuis, R. G. Visser, Y. Bai and R. Kormelink. 2014. Tomato yellow leaf curl virus resistance by Ty-1 involves increased cytosine 
methylation of viral genomes and is compromised by cucumber mosaic virus infection. Proceeding of the National Academy of Sciences, 111(35): 12942-12947.

Byrne, D. N., and T. S. Bellows Jr. 1991. Whitefly biology. Annual review of entomology, 36(1), 431-457.

Campbell, B. C. 1993. Congruent evolution between whiteflies (Homoptera: Aleyrodidae) and their bacterial endosymbionts based on respective $18 \mathrm{~S}$ and $16 \mathrm{~S}$ rDNAs. Current microbiology, 26(3), 129-132.

Caro, M., M. G. Verlaan, O. Julián, R. Finkers, A. M. A. Wolters, S. F. Hutton, and Y. Bai. 2015. Assessing the genetic variation of $\mathrm{Ty}-1$ and Ty-3 alleles conferring resistance to tomato yellow leaf curl virus in a broad tomato germplasm. Molecular Breeding, 35(6): 1-13.

Cohen, S., and F. E. Nitzany. 1960. Curly top virus of tomatoes: its identification and mode of transmission. Israeli Plant Protection and inspection Services.

Cohen, S., and M. Lapidot. 2007. Appearance and expansion of TYLCV: a historical point of view. In Tomato yellow leaf curl virus disease (pp. 3-12). Springer, Dordrecht.

Conflon, D., M. Graniera, F. Tiendrébéogo, P. Gentite, M. Peterschmitt and C. Urbino. 2018. Accumulation and transmission of alphasatellite, betasatellite and tomato yellow leaf curl virus in susceptible and Ty-1-resistant tomato plants. Virus research, 253: 124-134.

Cui, X., G. Li, D. Wang, D. Hu, and X. Zhou 2005. A begomovirus DNA $\beta$ - encoded protein binds DNA, functions as a suppressor of RNA silencing, and targets the cell nucleus. Journal of Virology, 79(16): 10764-10775.

Cui, X., X. Tao, Y. Xie, C.M. Fauquet and X. Zhou. 2004. A DNA $\beta$ associated with Tomato leaf curl china virus is required for symptom induction. Journal of Virology, 78(24): 1396613974.

Czosnek, H., M. Ghanim and M. Ghanim. 2002. The circulative pathway of begomoviruses in the whitefly vector Bemisia tabaci-insights from studies with Tomato yellow leaf curl virus. Annals of Applied Biology, 140(3): 215-231.

Dry, I.B., L.R. Krake, J.E. Rigden and M.A. Rezaian. 1997. A novel subviral agent associated with a geminivirus: the first report of a DNA satellite. Proceeding of the National Academy of Sciences, 94(13): 7088-7093.

El-Dougdoug, N. K., S. A. Mahfouze, S. A. Ahmed, B. A. Othman, and M. M. Hazaa. 2014. Characterization, Genetic Diversity of Tomato Yellow Leaf Curl Virus Egyptian Isolate. Scientia Agriculturae, 3(2): 58-69.

Fauquet, C. M., S. Sawyer, A. M. Idris, and J. K. Brown. 2005. Sequence analysis and classification of apparent recombinant begomoviruses infecting tomato in the Nile and Mediterranean basins. Phytopathology, 95: 549-555.

Fiallo-Olivé, E., Y. Martínez-Zubiaur, E. Moriones and J. Navas-Castillo. 2012. A novel class of DNA satellites associated with New World begomoviruses. Virology, 426(1): 1-6.

Fleischmann Jr, W. R. 1996. Viral genetics. Medical Microbiology. $4^{\text {th }}$ edition.

Gabriadze, I., T. Kutateladze, B. Vishnepolsky, M. Karseladze and N. Datukishvili. 2014. Application of PCR-based methods for rapid detection of corn ingredients in processed foods. International Journal of Nutrition and Food Sciences, 3(3): 199-202.

Garcia-Andres, S., F. Monci, J. Navas-Castillo and E. Moriones. 2006. Begomovirus genetic diversity in the native plant reservoir Solanum nigrum: evidence for the presence of a new virus species of recombinant nature. Virology, 350: 433-442.

Gilbertson, R. L., O. Batuman, C. G. Webster and S. Adkins. 2015. Role of the insect supervectors Bemisia tabaci and Frankliniella occidentalis in the emergence and global spread of plant viruses. Annual review of virology, 2: 67-93.

Gill, R. J. (1990). The morphology of whiteflies. In D. Gerling (Ed.), Whiteflies: Their Bionomics, Pest Status, and Management. Andover, Hants, England: Intercept, 13-45.

Gorovits, R., \& Czosnek, H. (2013). Insect symbiotic bacterial GroEL (Chaperonin 60) and plant virus transmission. In Moonlighting Cell Stress Proteins in Microbial Infections (pp. 173187). Springer, Dordrecht.

He, Y. Z., Y. M. Wang, T. Y. Yin, E. FialloOlivé, Y. Q. Liu, L. Hanley-Bowdoin, and X. W. Wang. 2020. A plant DNA virus replicates in the salivary glands of its insect vector via recruitment of host DNA synthesis machinery. Proceedings of the National Academy of Sciences, 117(29): 16928-16937.

Idris, A. M., M. H. Hussein, A. M. Abdel-Salam, and J. K. Brown. 2002. Phylogenetic relationships for okra leaf curl-and hollyhock leaf crumple-associated begomoviruses and first report of associated satellite DNAs. Arab Journal of Biotechnology, 5: 67-82.

Idris, A.M., R.W. Briddon, S.E. Bull and J.K. Brown. 2005. Cotton leaf curl Gezira virussatellite DNAs represent a divergent, geographically isolated Nile Basin lineage: Predictive identification of a sat DNA REFbinding motif. Virus research, 109: 19-32.

Idris, A. M., M. S. Shahid, R. W. Briddon, A. J. Khan, J. K. Zhu, and J. K. Brown. 2011. An unusual alphasatellite associated with monopartite begomoviruses attenuates 
symptoms and reduces betasatellite accumulation. Journal of General Virology, 92(3): 706-717.

Ito, T., J. Kimbara, P. Sharma and M. Ikegami. 2009. Interaction of tomato yellow leaf curl virus with diverse betasatellites enhances symptom severity. Archives of virology, 154(8): 1233 1239.

Jeske, H. 2009. Geminiviruses. TT viruses, 185226.

Kheyr-Pour, A., M. Bendahmane, V. Matzeit, G. P. Accotto, S. Crespi and B. Gronenborn. 1991. Tomato leaf curl from Sardinia is a whitefly-transmitted monopartite geminivirus. Nucleic acids research, 19 (24): 6763-6769.

Kon, T., M. R. Rojas, I. K. Abdourhamane and R. L. Gilbertson. 2009. Roles and interactions of begomoviruses and satellite DNAs associated with okra leaf curl disease in Mali, West Africa. Journal of General Virology, 90(4): 1001-1013.

Lazarowitz, S. G. and R. J. Shepherd. 1992. Geminiviruses: genome structure and gene function. Critical Reviews in Plant Sciences, 11(4): 327-349.

Lefeuvre, P., D. P. Martin, G. Harkins, P. Lemey, A. J. Gray, S. Meredith, and J. Heydarnejad. 2010. The spread of tomato yellow leaf curl virus from the Middle East to the world. PLoS Pathogens, 6(10): e1001164.

Mabvakure, B., D. P. Martin, S. Kraberger, L. Cloete, S. Brunschot, A. D. W. Geering, J. E. Thomas, K. Bananej, J. Lett, P. Lefeuvre, A. Varsani and G. W. Harkins. 2016. Ongoing geographical spread of Tomato yellow leaf curl virus. Virology, 498: 257-264.

Maio, F., T. A. Helderman, M. Arroyo-Mateos, M. van der Wolf, S. Boeren, M. Prins and H. A. van den Burg. 2020. Identification of tomato proteins that interact with replication initiator protein (Rep) of the geminivirus TYLCV. Frontiers in plant science, 11, 1069.

Mansoor, S., R. W. Briddon, Y. Zafar and J. Stanley.2003. Geminivirus disease complexes: an emerging threat. Trends in plant science, 8(3): 128-134.

Mansoor, S., Y. Zafarand R.W. Briddon. 2006. Geminivirus disease complexes: the threat is spreading. Trends in plant science, 11(5): 209 212.

Matole, O. H. (2018). A Study of the Southern African Begomovirus Pathosystem: Determining the Diversity of Whitefly Transmitted Geminiviruses (WTG) Infecting Indigenous Plants in South Africa. University of Johannesburg (South Africa).

Morin, S., Ghanim, M., Zeidan, M., Czosnek, H., Verbeek, M., \& Van Den Heuvel, J. F. 1999. A GroEL homologue from endosymbiotic bacteria of the whiteflyBemisia tabaciis implicated in the circulative transmission of tomato yellow leaf curl virus. Virology, 256(1): 75-84

Moury, B. and E. Verdin.2012. Viruses of pepper crops in the Mediterranean basin: a remarkable stasis. Advances in virus research, 84: 127-162.

Navas-Castillo, J., E. Fiallo-Olivé and S. Sánchez-Campos.2011. Emerging virus diseases transmitted by whiteflies. Annual review of phytopathology, 49: 219-248.

Ohnishi, J., H. Yamaguchi, and A. Saito.2016. Analysis of the Mild strain of tomato yellow leaf curl virus, which overcomes Ty-2 genemediated resistance in tomato line $\mathrm{H} 24$. Archives of virology, 161(8): 2207-2217.

Rabie, M., C. Ratti, E. A. Aleem and F. Fattouh. 2017. Detection and molecular characterization of tomato yellow leaf curl virus naturally infecting Lycopersicon esculentum in Egypt. Acta virologica, 61(3): 252-263.

Rosell, R. C., Blackmer, J. L., Czosnek, H., \& Inbar, M. (2009). Mutualistic and dependent relationships with other organisms. In Bemisia: Bionomics and management of a global pest (pp. 161-183). Springer, Dordrecht.

Rosen, R., S. Kanakala, A. Kliot, B. C. Pakkianathan, B. A. Farich, N. SantanaMagal and M. Ghanim. 2015. Persistent, circulative transmission of begomoviruses by whitefly vectors. Current Opinion in Virology, 15: 1-8.

Saeed, M. 2010. Tomato leaf curl virus and Cotton leaf curl Multan betasatellite can cause mild transient symptoms in cotton. Australasian Plant Disease Notes, 5(1): 58-60.

Saunders, K., A. Norman, S. Gucciardo and J. Stanley 2004. A DNA $\beta$ satellite component associated with ageratum yellow vein disease encodes an essential pathogenicity protein $(\beta C 1)$. Virology, 324: 37-47.

Sivalingam, P. N. and A. Varma. 2012. Role of betasatellite in the pathogenesis of a bipartite begomovirus affecting tomato in India. Archives of virology, 157(6): 1081-1092.

Sofy, A. R., K. A. El-Dougdoug, A. A. Mousa and E. E. Refaey. 2017. Impact of two TYLCV Egyptian isolates on metabolic and antioxidant activities in some tomato cultivars. International Journal of Advanced Research in Biological Sciences, 4(2): 110-133.

Thao, M. L., and P. Baumann. 2004.

Evolutionary relationships of primary prokaryotic endosymbionts of whiteflies and their hosts. Applied and Environmental Microbiology, 70(6), 3401-3406.

Ueda, S., M. Onuki, M. Yamashita and Y. Yamato. 2012. Pathogenicity and insect 
transmission of a begomovirus complex between tomato yellow leaf curl virus and Ageratum yellow vein betasatellite. Virus genes, 44(2): 338-344.

Verlaan, M. G., S. F. Hutton, R. M. Ibrahem, R. Kormelink, R. G. Visser, J. W. Scott and Y. Bai. 2013. The tomato yellow leaf curl virus resistance genes Ty-1 and Ty-3 are allelic and code for DFDGD-class RNA-dependent RNA polymerases. PLoS Genetics, 9(3): e1003399.

Voorburg, C. M., Z. Yan, M. Bergua-vidal, A. A. Wolters, Y. BAI, and R. Kormelink. 2020. Ty-1, a universal resistance gene against geminiviruses that is compromised by coreplication of a betasatellite. Molecular Plant Pathology, 21(2): 160-172.
Yamaguchi, H., J. Ohnishi, A. Saito, A. Ohyama, T. Nunome, K. Miyatake and $H$. Fukuoka. 2018. An NB-LRR gene, TYNBS1, is responsible for resistance mediated by the Ty-2 Begomovirus resistance locus of tomato. Theoretical and Applied Genetics, 131(6): 1345 1362.

Zhao, L., K. Rosario, M. Breitbart, and S. Duffy. 2019. Eukaryotic circular rep-encoding single-stranded DNA (CRESS DNA) viruses: ubiquitous viruses with small genomes and a diverse host range. Advances in virus research, 103: 71-133.

Zhang, J., J. Dong, Y. Xu, and J. Wu. 2012. V2 protein encoded by Tomato yellow leaf curl China virus is an RNA silencing suppressor. Virus research, 163(1): 51-58. 


\section{الملخص العربى \\ دارسات جزيئية على فيروس تجعد الأوارق الأصفر فى الطماطم على نباتي الطماطم والفلفل}

\section{حسني على يونس 1 و نهال عبدالمجيد زبـ2 و سحر دارز2}

1- قسم النبات الزارعي، كلية الزارعة - سابا باشا ، جامعة الأسكندرية، مصر

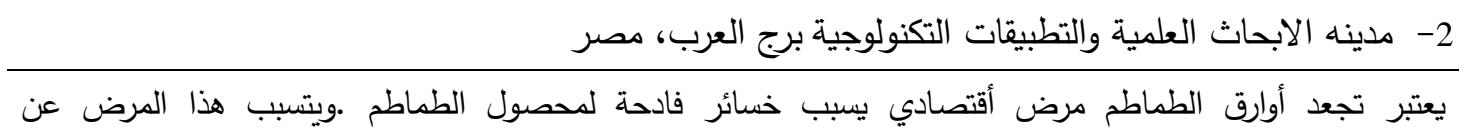

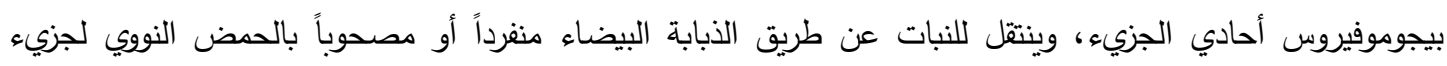

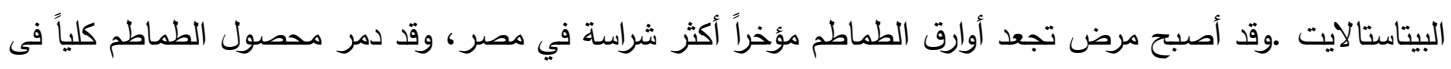

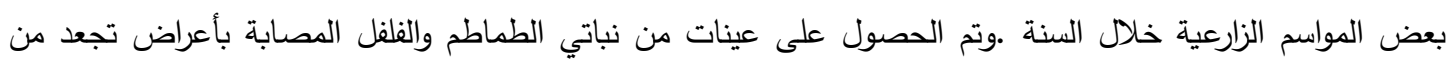
من خلال البوادئ المتخصصة (PCR) منطقة النوبارية في مصر ، وتم أختبارها بواسطة التقاعل المتسلسل لأنزيم البلمرة والبوادئ واسعة الددى للكثف عن وجود البيجوموفيروس المسبب، أو البيتاستالايت المرتبطة به أو أى مؤتلفات جديدة

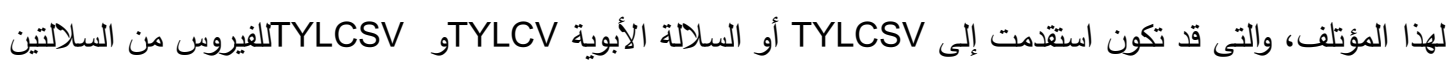

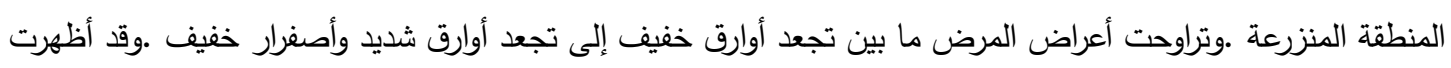

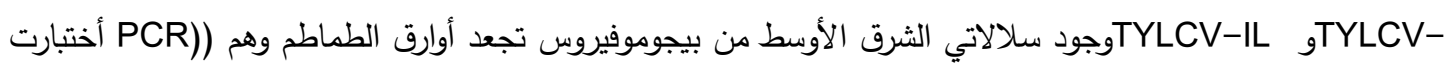

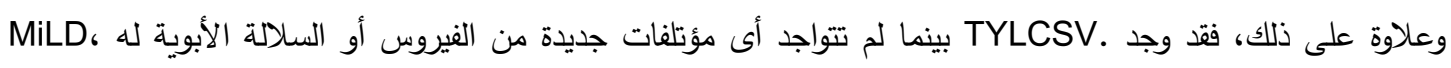

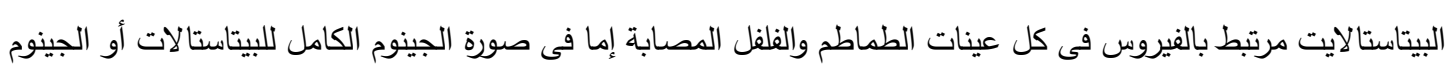

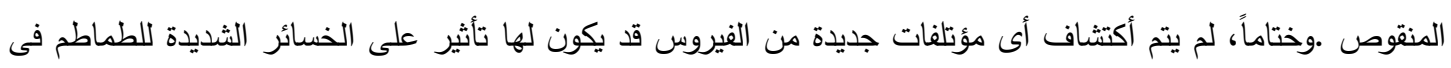

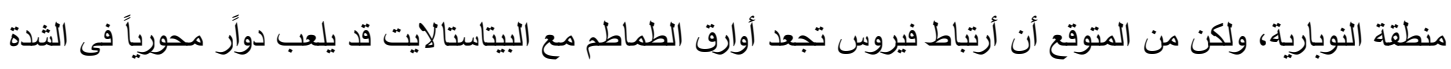

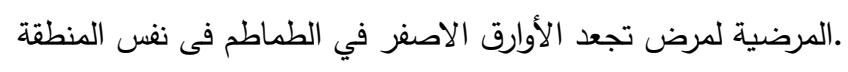

